\title{
PENDIDIKAN KETERAMPILAN PERDAMAIAN UNTUK SISWA SEKOLAH LENTERA HARAPAN JATI AGUNG
}

\author{
Edwin M. B. Tambunan', Elyzabeth B. Nasution² \\ ${ }^{1}$ Program Studi Hubungan Internasional, Universitas Pelita Harapan \\ ${ }^{2}$ Program Studi Hubungan Internasional Universitas Pelita Harapan \\ edwin.tambunan@uph.edu, elyzabeth.nasution@uph.edu
}

\begin{abstract}
Abstrak
Menciptakan dan mempertahankan perdamaian secara berkesinambungan harus menjadi prioritas dalam bangsa yang memiliki keragaman seperti bangsa Indonesia. Salah satu upaya konkrit yang bisa dilakukan untuk mewujudkan hal ini adalah melalui proses pendidikan. Caranya adalah dengan menjangkau dan melatih sebanyak mungkin kelompok-kelompok yang ada dalam masyarakat untuk memiliki keterampilan perdamaian. Kelompok usia yang menjadi sasaran strategis untuk dijangkau dalam masyarakat adalah kelompok remaja. Sekolah Lentera Harapan Jati Agung dirasakan perlu mendapatkan pendidikan keterampilan perdamaian karena berada di Provinsi Lampung yang tinggi tingkat kriminalitas, rawan konflik, dengan mayoritas siswa berasal dari keluarga dengan kemampuan ekonomi menengah ke bawah yang rawan terpapar faktor-faktor penyebab konflik. Kegiatan berlangsung dalam bentuk pelatihan partisipatoris dengan menggunakan sembilan modul yang melibatkan siswa sekolah dalam serangkaian kegiatan interaktif. Pendekatan yang digunakan ialah Konstruktivisme dengan beberapa metode, antara lain curah pendapat, diskusi, studi kasus, dinamika kelompok, kerja kelompok, bermain peran, bercerita, visualisasi, dan dramatisasi. Hasil kegiatan mengacu pada tujuan awal yaitu agar para siswa diperlengkapi dengan wawasan, pengetahuan, dan keterampilan perdamaian. Hal ini terukur dari instrumen pre-test dan post-test, evaluasi para fasilitator, serta evaluasi peserta. Secara keseluruhan kegiatan berlangsung baik dan memberi pengaruh terhadap pengetahuan siswa mengenai konflik dan perdamaian.
\end{abstract}

Kata Kunci: pendidikan perdamaian, resolusi konflik, sekolah lentera harapan jati agung, pengabdian masyarakat

\section{PENDAHULUAN}

\section{A. Latar Belakang, Urgensi, dan Rasionalitas}

Di dalam salah satu bukunya, salah seorang pakar terkemuka di bidang konflik dan perdamaian, John Paul Lederach, mengemukakan bahwa upaya membangun perdamaian bukanlah pekerjaan mudah (Lederach, 2003). Tidaklah juga upaya yang hasilnya bisa didapatkan dalam waktu singkat, karena transformasi yang dilakukan dalam rangka membangun perdamaian memerlukan proses panjang. Membangun perdamaian ibarat menyusun gambar dalam jigsaw puzzle. Bentuk utuh baru terlihat setelah proses panjang menggabungkan potongan-potongan gambar berhasil dilakukan. 'Peace by Piece', demikian ungkapan yang sering dipakai untuk menggambarkan proses dimaksud. Di dalam buku yang sama, Lederach juga menjelaskan kepada kita bahwa membangun perdamaian tidak harus top-down. Transformasi bisa dimulai dari halhal sederhana dan kecil. Prosesnya berlangsung dari

$$
\text { Pendidikan }
$$


bawah atau dikenal dengan istilah peacebuilding from below (Ramsbotham, Woodhouse \& Miall, 2008, pp. 217-221).

Program Studi Hubungan Internasional, Fakultas Ilmu Sosial dan Ilmu Politik, Unversitas Pelita Harapan berupaya terlibat dalam membangun perdamaian dari bawah dengan menjadikan remaja atau pelajar di tingkat Sekolah Menengah Atas (SMA) sebagai target kegiatan. Untuk itu, Program Studi Hubungan Internasional, Universitas Pelita Harapan menyelenggarakan Pelatihan Keterampilan Perdamaian dan Resolusi Konflik untuk siswa ke berbagai sekolah dengan latar belakang yang berbeda-beda, baik dari segi lokasi, kemampuan ekonomi masyarakat sekitar, dan latar belakang agama.

Jalur pendidikan ditempuh karena selaras dengan pernyataan yang dicetuskan dalam Konstitusi United Nations Educational, Scientific, and Cultural Organization (UNESCO), yaitu "Since wars begin in the minds of men, it is in the minds of men that the defenses of peace must be constructed". Untuk menciptakan dan mempertahankan perdamaian, diperlukan upaya serius mengkonstruksi pikiran manusia. Salah satu upaya yang bisa dilakukan ke arah sana adalah melalui proses pendidikan. Untuk mencegah konflik berkembang dan meluas di masa mendatang maka sebanyak mungkin kelompok-kelompok yang ada dalam masyarakat, utamanya para siswa, perlu dijangkau dan dilatih untuk memiliki keterampilan perdamaian.

Salah satu sekolah yang menjadi target pelaksanaan program pelatihan di tahun 2020 adalah Sekolah Lentera Harapan, Jati Agung, Lampung. Sekolah ini dinilai perlu mendapatkan Pelatihan Keterampilan Perdamaian dan Resolusi Konflik karena berada di daerah dengan karakteristik rawan konflik sosial.

Di tahun 2015, Komisi Nasional Hak Asasi Manusia (Komnas HAM) menyebutkan Lampung sebagai tiga besar daerah rawan konflik di Indonesia (Muslihah, 2015). Hingga tahun 2019, daerah Lampung masih menjadi daerah rawan konflik. Ditambah dengan latar belakang ekonomi masyarakatnya yang tergolong menengah ke bawah, masyarakat di Lampung punya tantangan lebih kompleks dalam menjaga keamanan dan ketenteraman.

Selain karena karakteristik lokasi, Sekolah Lentera Harapan Jati Agung juga dipilih karena memiliki siswa-siswi yang sesuai dengan sasaran usia dari Modul Pendidikan Perdamaian yang rentang usianya 10-24 tahun. Para siswa/i dalam kelompok usia ini akan menjadi generasi baru pemimpin dalam dua dekade mendatang. Pembekalan keterampilan perdamaian bagi kelompok usia ini tentu akan sangat berguna untuk menciptakan generasi pemimpin yang mampu menghadirkan solusi-solusi terhadap konflikkonflik di masa yang akan datang. Kelompok usia ini merupakan sasaran strategis dalam menyebarluaskan ide-ide tentang perdamaian. Apabila kelompok ini dibekali keterampilan perdamaian dan mereka kemudian mewarisinya hingga usia dewasa, peluang masyarakat kita mengalami perpecahan akibat konflik di masa mendatang bisa diperkirakan akan semakin mengecil (Tambunan, 2008).

Selain alasan-alasan di atas, keberadaan Sekolah Lentera Harapan Jati Agung di tengah lingkungan masyarakat sekitar yang mayoritas beragama non-Kristen, menyebabkan Sekolah Lentera Harapan Jati Agung juga butuh penguatan dalam peran dan interaksi dengan masyarakat sekitar. Kegiatan Pengabdian kepada Masyarakat ini diharapkan membantu penguatan pemahaman siswa tentang pentingnya menjaga perdamaian demi persatuan bangsa dan negara. Dengan demikian, meski berlokasi di daerah yang rawan konflik, siswa Sekolah Lentera Harapan Jati Agung diharapkan bisa menerapkan nilai-nilai Kristiani secara bijak untuk mendukung ketenteraman dalam masyarakat.

Dengan sejumlah tantangan seperti dikemukakan di atas, para siswa yang belajar di Sekolah Lentera Harapan Jati Agung dinilai sangat perlu mendapatkan pendidikan keterampilan perdamaian, Melalui pelatihan, siswa akan memiliki wawasan, pengetahuan, dan keterampilan yang benar tentang cara menangani konflik dan mengembangkan budaya perdamaian, selain mendapatkan sejumlah keterampilan dasar untuk menerapkan pengetahuan dan orientasi perilaku baru tentang perdamaian. Setelah mengikuti

$$
\text { Pendidikan }
$$


program ini diharapkan potensi terjadinya konflik di antara para siswa yang memiliki ragam latar belakang suku, etnis, dan agama, atau mereka terpapar dengan konflik di luar sekolah, bisa semakin diminimalkan.

Selain itu, dalam jangka panjang, dengan adanya pelatihan yang berlangsung secara konsisten dan teratur, diharapkan para siswa akan memiliki identitas diri, rasa kebangsaan, dan kebanggaan yang kuat sebagai warga negara Indonesia sekaligus sebagai peserta didik dari Sekolah Lentera Harapan Jati Agung.

\section{B. Kerangka Pemikiran}

Setiap orang yang belajar Studi Hubungan Internasional (SHI) mengetahui secara pasti bahwa salah satu motivasi awal pembentukan SHI adalah untuk membantu umat manusia keluar dari ancaman peperangan besar. Dengan kata lain, melalui bidang pendidikan, SHI diharapkan memberi kontribusi untuk mendorong terciptanya perdamaian global. Kajian-kajian yang dihasilkan SHI diharapkan memberikan sumbangan kebijaksanaan (wisdom) atau penjelasan rasional (science) kepada para pembuat keputusan, agar mereka berdaya untuk mengendalikan negara terhindar dari konflik dan peperangan, atau bisa mengendalikan stabilitas global. Hanya saja, sesuai dengan kapasitas dan peran penting yang dimiliki negara saat itu, sejumlah pendekatan yang berkembang pada fase awal pembentukan SHI, seperti Idealisme dan Realisme, cenderung bersifat state-centrist, termasuk dalam mengkaji perdamaian global. Peran dari aktor-aktor non-negara dalam membangun perdamaian global, khususnya individu, jauh dari radar diskusi akademik. Situasi ini berlanjut terus selama puluhan tahun, hingga dekade 1970-an ketika perspektif Pluralisme akhirnya membuka ruang untuk mendiskusikan peran aktor yang lebih beragam, termasuk aktor individu (Maghroori \& Ramberg, 1984).

Pada saat yang hampir bersamaan dengan berkembangnya Pluralisme, tumbuh dan berkembang kesadaran bahwa perdamaian dunia tidak bisa dipaksakan melalui proses global, yaitu hanya dengan menggunakan instrumen organisasi global seperti Perserikatan Bangsa-Bangsa (PBB) misalnya. Berkembang pemahaman bahwa transformasi menuju perdamaian global baru bisa dilakukan apabila seluruh negara menginginkan perdamaian. Lebih jauh, proses membangun negaranegara yang damai ini akan berkelanjutan apabila dilaksanakan melalui transformasi dari bawah. Dimulai dari tingkat akar rumput atau dari individu. Mengikuti penalaran ini maka hanya di dalam masyarakat yang individu-individu anggotanya hidup dalam damai, pada akhirnya berkembang negara yang damai.

Arthur Stein, salah seorang penganjur pendekatan transformatif menuju perdamaian global, mengemukakan bahwa di masa lalu peran individu cenderung diabaikan dalam upaya membangun tatanan dunia yang damai dan adil. Padahal, menurut Stein, upaya membangun perdamaian global justru akan semakin efektif apabila dimulai dari tingkat akar rumput atau dari individu. Perubahan global sangat mungkin berlangsung positif apabila individu semakin bertambah pemahaman dan kesadarannya bahwa hidup dalam suasana damai lebih menguntungkan mereka. Kesadaran seperti ini akan membuat individu berkomitmen untuk menjaga perdamaian. Dengan semakin banyaknya individu, kelompok, dan masyarakat mengambil bagian dalam proses ini, maka hubungan antarbangsa maupun antarnegara akan ikut mengalami perubahan dan semakin terbuka menuju perdamaian global (Stein, 2004, pp. 565-581).

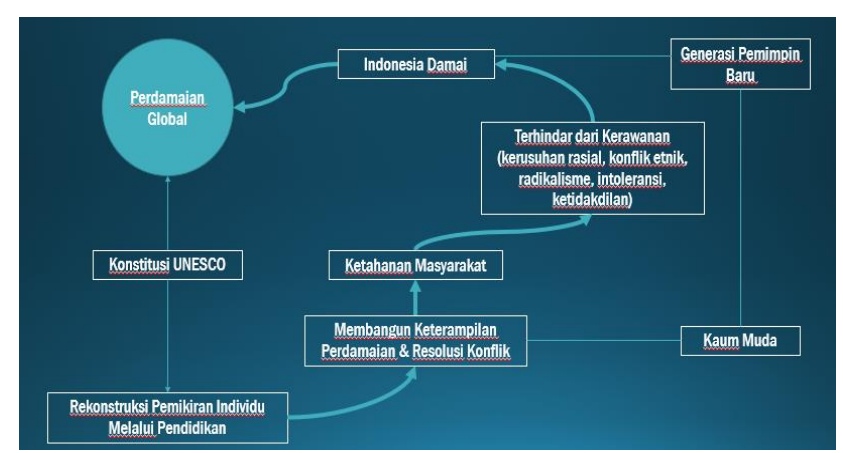

Gambar 1. Kerangka Pemikiran

Sebagai negara yang memiliki tujuan nasional ikut "melaksanakan ketertiban dunia yang berdasarkan kemerdekaan, perdamaian abadi, dan keadilan sosial", sudah seyogianya Indonesia memiliki masyarakat yang hidup dalam damai dan 
menjadi negara yang damai. Hanya sayangnya, hingga saat ini Indonesia belum bisa sepenuhnya terhindar dari kerawanan sosial, ekonomi, dan politik. Segala kerawanan ini sewaktu-waktu bisa pecah menjadi konflik apabila masyarakat tidak memiliki keterampilan mengelola perbedaan dan potensi konflik. Untuk mencegah situasi demikian terjadi di masa mendatang, sudah barang tentu diperlukan langkah sistematis dan terencana. Pendekatan transformatif diperkirakan bisa membantu secara efektif langkah-langkah dalam melakukan pencegahan ini.

Salah satu kelompok usia dalam masyarakat yang signifikan jumlahnya dan akan menjadi generasi baru pemimpin dalam dua dekade mendatang adalah kelompok remaja yang saat ini duduk di bangku Sekolah Menengah Atas (SMA). Remaja perlu mendapat perhatian sungguh-sungguh karena di kelompok usia ini berlangsung fase perkembangan psikososial yang dikenal dengan "identitas versus kebingungan". Di dalam kelompok usia ini perlu dibangun rasa identitas pribadi sebagai bagian dari kelompok sosial. Kegagalan untuk membangun identitas akan mengakibatkan kebingungan tentang siapa mereka dan apa yang mereka lakukan dalam hidup (Sandy, 2006, pp. 356358).

Apabila kelompok ini dibekali keterampilan perdamaian dan mereka kemudian mewarisinya hingga usia dewasa, akan semakin kecil peluang masyarakat kita mengalami perpecahan dan konflik di masa mendatang. Untuk itu, sebuah kegiatan pendidikan keterampilan perlu dilakukan agar individu pada kelompok usia ini tidak hanya tahu dan paham tentang nilai-nilai perdamaian, tetapi bisa menerapkannya secara langsung dalam berbagai situasi sosial nyata yang mereka hadapi. Melalui proses ini diharapkan terjadi transformasi di kalangan generasi muda Indonesia yang akan mengubah wajah Indonesia menjadi negara yang sungguh-sungguh cinta perdamaian dan akhirnya semakin maksimum berperan dalam mewujudkan perdamaian global.

Pemahaman ini sejalan dengan model pendidikan perdamaian yang ditawarkan Alev Yemenici. Upaya menanamkan kesadaran pentingnya perdamaian harus menargetkan tiga kelompok besar: anak-anak (termasuk peserta Taman Kanak-kanak, Sekolah Dasar, dan Sekolah Menengah Pertama) remaja/dewasa muda (termasuk peserta didik Sekolah Menengah Atas dan mahasiswa), serta kelompok dewasa (orang tua/calon orang tua, pendidik, hingga kaum profesional muda/produktif). Bentuk pendidikan perdamaian yang dipaparkan untuk tiap kelompok boleh jadi akan berbeda, tapi esensi nilai yang disampaikan tetap sama (Yemenici, 2016, pp. 7-9).

Dalam SHI, para penstudi kian cemas dengan berkembangnya gagasan "no war, no peace", yang mengindikasikan bahwa proses pencapaian perdamaian yang tidak didahului bentuk-bentuk kekerasan dan penderitaan, akan membuat para pemangku kepentingan sulit mencapai kata sepakat mewujudkan perdamaian karena mereka merasa nyaman dengan tidak adanya peperangan yang harus dihentikan (Mac Ginty, 2016). Jika dibiarkan, maka definisi perdamaian negatif - damai berarti ketiadaan perang - akan mendominasi, padahal perdamaian negatif selalu bersifat sementara. Bentuk perdamaian positif yang ditandai dengan ketiadaan kekerasan struktural dan kultural - merupakan bentuk ideal perdamaian yang ingin dicapai. Perdamaian negatif sarat akan absensi kekerasan langsung/fisik dan banyak pihak berhenti di sini. Namun, perdamaian tidak akan utuh jika masih ada relasi buruk di antara ragam etnis, kelas, agama; atau jika masih ada bentuk kekerasan struktural dan/atau kultural; atau jika masih ada penderitaan yang disebabkan faktor politik dan ekonomi; serta jika masih ada bentuk-bentuk eksploitasi dan represi (Galtung \& Fischer, 2013). Dengan demikian adalah keliru jika kita menilai bahwa perdamaian sudah tercapai dengan menyandarkan diri pada keadaan tanpa perang.

Lebih lagi, urgensi pendidikan perdamaian di Indonesia berangkat dari fakta bahwa perjalanan konsolidasi demokrasi Indonesia kerap diwarnai dengan kekerasan yang pelakunya adalah para pemuda. Perbedaan menjadi penyebab utama yang kian diperparah oleh konteks politik global yang diramaikan isu terorisme. Jika tidak segera ditangani, kaum muda Indonesia hanya akan tumbuh menjadi pribadi yang gemar kekerasan dan intoleran terhadap perbedaan (Nasution, 2017). Perlu ditekankan, tumbuh dan berkembangnya

$$
\text { Pendidikan }
$$

732 
kelompok vigilante - yang didominasi oleh kaum remaja/dewasa muda - yang gemar menggunakan kekerasan dan main hakim sendiri (Firawati, 2015) merupakan indikator betapa perdamaian adalah isu krusial yang sering terlewatkan. Artinya Indonesia masih jauh dari pencapaian perdamaian positif mengingat besar dan intensifnya bentuk kekerasan langsung/fisik yang ditemukan.

\section{METODE}

Berdasarkan kerangka pemikiran yang diutarakan di atas, Program Studi Hubungan Internasional, Universitas Pelita Harapan mengembangkan program Pengabdian kepada Masyarakat yang memusatkan perhatian pada pendidikan perdamaian. Program ini dirancang tahun 2017 dan diberi nama Pendidikan Keterampilan Perdamaian dan Resolusi Konflik. Tujuan dari program ini ada dua. Pertama, menanamkan secara dini ke dalam diri remaja nilainilai kehidupan yang memampukan mereka untuk hidup dalam damai di tengah-tengah masyarakat yang majemuk. Kedua, mencegah secara dini kecenderungan penggunaan kekerasan di antara mereka.

Bentuk kegiatan yang dipilih untuk program Pendidikan Keterampilan Perdamaian dan Resolusi Konflik adalah lokakarya (workshop) dan pelatihan (training). Lokakarya menjadi pilihan bentuk kegiatan karena melalui kegiatan ini peserta mendapat kesempatan seluas mungkin untuk terlibat aktif. Keterlibatan peserta mendapat perhatian penting dalam program yang dirancang untuk memenuhi salah satu prinsip membangun perdamaian dari bawah (peace from below) yaitu partisipatoris. Selain itu, melalui lokakarya, peserta bisa belajar lewat pengalaman mereka. Lokakarya juga memberi peluang seluas mungkin bagi peserta untuk belajar bekerja sama memecahkan masalah bersama (Raider, Coleman \& Gerson 2006, pp. 695725). Dalam program yang dirancang, lokakarya dikombinasikan dengan pelatihan. Bentuk pelatihan sengaja dipilih karena materi perdamaian dan resolusi konflik juga sarat dengan keterampilan yang harus dimiliki dan dikembangkan setiap peserta. Keterampilan-keterampilan tersebut akan bisa diterapkan dengan baik apabila peserta mendapatkan pengalaman langsung berlatih menggunakannya.

Adapun metode pelaksanaan atau langkahlangkah yang digunakan dalam kegiatan Pengabdian kepada Masyarakat ini adalah sebagai berikut: 1) penjajakan; 2) persiapan materi, fasilitator, dan pengelolaan pelatihan; 3) pelaksanaan pelatihan yang menitikberatkan pada pola, pendekatan, serta metode; dan 4) umpan balik.

Proses penjajakan terhadap Sekolah Lentera Harapan Jati Agung dilakukan melalui komunikasi langsung dengan kepala sekolah. Koordinasi dan konsolidasi sudah dilakukan sejak Juli 2019. Kegiatan Pengabdian kepada Masyarakat disepakati berlangsung pada tanggal 10-14 Februari 2020.

Sebanyak sembilan modul dipersiapkan untuk disampaikan selama pelatihan. Modul berdurasi antara 45 menit hingga 120 menit, mencakup topiktopik: toleransi, pengampunan, tanggung jawab, kerja sama, kerendahan hati, kejujuran, keadilan, persatuan, dan resolusi konflik.

Langkah penyusunan materi diikuti kemudian dengan Training for Trainer bagi dosendosen yang bertugas sebagai fasilitator sebelum keberangkatan ke Lampung. Fasilitator, yang terdiri dari empat orang dosen dan satu asisten dosen, dibantu enam mahasiswa mempersiapkan perlengkapan pelatihan serta memandu seluruh aktivitas pada saat pelaksanaan kegiatan dengan mengacu kepada instruksi yang tercantum dalam modul. Setiap fasilitator memfasilitasi 25 hingga 30 siswa. Untuk setiap kelompok, fasilitator didampingi ko-fasilitator beserta seorang guru yang ikut belajar teknik memfasilitasi. Dalam tahap persiapan ini, asisten dosen membantu Ketua Tim dalam mempersiapkan modul dan dalam melakukan monitoring saat pelatihan berlangsung. Mahasiswa bersama asisten dosen dilibatkan untuk membantu hal-hal teknis terkait dengan administrasi, transportasi, dan logistik.

Pelaksanaan kegiatan Pengabdian kepada Masyarakat berlangsung dalam bentuk pelatihan partisipatoris. Untuk sembilan modul yang disiapkan, peserta terlibat dalam serangkaian kegiatan interaktif. Setiap modul memiliki pola kegiatan yang sama, yaitu: 1) Kegiatan Pendahuluan - yang dimaksudkan untuk menciptakan suasana 
awal dan mengarahkan perhatian siswa agar mengikuti pembelajaran dengan baik dan hati yang riang. Kegiatan Pendahuluan terdiri dari nyanyian, permainan ringan, atau cerita pendek; 2) Kegiatan Inti - bertujuan untuk mencapai sasaran-sasaran belajar yang ditetapkan pada setiap topik. Jumlah kegiatan pada setiap topik beragam, mengikuti sasaran yang harus dicapai; 3) Kegiatan Penutup dimaksudkan sebagai penegasan makna pembelajaran dan penenangan. Kegiatan berbentuk cerita, nyanyian, atau permainan.

Tugas utama fasilitator dalam kegiatan ini bukanlah mengajar, tetapi sebatas menjelaskan halhal yang harus dilakukan siswa, menyediakan bahan-bahan yang dibutuhkan, dan memandu proses. Dengan demikian para peserta belajar langsung dari kegiatan pembelajaran yang dilakukan dan mengkonstruksikan sendiri makna maupun isi pembelajaran melalui pengalaman belajar yang mereka dapatkan. Fasilitator hanya perlu memberikan penegasan-penegasan di akhir kegiatan pembelajaran.

Penyajian kegiatan pembelajaran dirancang menggunakan metode-metode yang bersifat partisipatoris dan interaktif. Metode-metode yang digunakan dalam modul ini mencakup: 1) curah pendapat; 2) diskusi; 3) studi kasus; 4) dinamika kelompok; 5) kerja kelompok; 6) bermain peran; 7) bercerita; 8) visualisasi; dan 9) dramatisasi.

Umpan balik dari pembelajaran yang dilakukan bukan diperoleh di akhir kegiatan melalui ujian atau bentuk-bentuk lain yang menyerupai ujian. Umpan balik diperoleh sepanjang proses pembelajaran dengan mengamati tanggapan siswa dalam tahap demi tahap kegiatan. Kegiatan pembelajaran dianggap berhasil apabila siswa dapat mengerjakan seluruh tahapan kegiatan dan dapat mengkonstruksikan makna pembelajaran sesuai dengan indikator untuk masing-masing topik. Mengingat modul ini sarat dengan pendidikan nilai maka keseluruhan proses pembelajaran dianggap berhasil apabila siswa mengalami perubahan sikap dan watak. Untuk keperluan evaluasi internal, tim pelaksana menyiapkan lembar pre-test dan post-test serta lembar evaluasi kegiatan yang diisi oleh peserta.

\section{HASIL DAN PEMBAHASAN}

Kegiatan Pengabdian kepada Masyarakat bertajuk Pendidikan Keterampilan Perdamaian dan Resolusi Konflik di Sekolah Lentera Harapan Jati Agung berlangsung tiga hari, 11-13 Februari 2020. Dalam pelaksanaannya, sembilan modul pelatihan yang telah disiapkan, disajikan tiga modul per hari.

Sebanyak 135 siswa berpartisipasi dalam kegiatan ini. Para siswa dikelompokkan ke dalam lima kelas. Di hari pertama, para siswa mendapatkan pelatihan untuk mengembangkan kesadaran dan keterampilan tentang toleransi, pengampunan, dan tanggung jawab. Lanjut di hari kedua, para siswa mendapatkan pelatihan tentang kerja sama, kerendahan hati, dan kejujuran. Pada hari terakhir, para siswa berlatih untuk menumbuhkan keadilan, persatuan, dan keterampilan resolusi konflik.

Meskipun dengan materi pelatihan yang diberikan, tidak akan terlihat langsung dan segera perubahan sikap dari para peserta, tim pelaksana berusaha mendapatkan gambaran awal dampak dari pelaksanaan program melalui dua macam instrumen. Untuk mendapatkan gambaran tentang pandangan peserta terhadap proses pelatihan yang dilakukan, para siswa diminta untuk mengisi lembar evaluasi setelah menyelesaikan pelatihan. Tim pelaksana juga berusaha mendapatkan gambaran awal tentang dampak dari pelatihan terhadap siswa. Untuk itu, disiapkan lembar pre-test yang dibagikan sebelum pelatihan dan lembar post-test setelah siswa rampung menyelesaikan pelatihan.

\section{Evaluasi Proses}

Lembar evaluasi kegiatan yang diisi oleh para siswa mencakup tujuh indikator, yaitu: 1) isi materi pelatihan; 2) efisiensi penggunaan waktu; 3) penguasaan materi oleh fasilitator; 4) pembawaan materi oleh fasilitator; 5) pencapaian sasaran program; 6) metode pelatihan, serta 7) penguasaan kelas dan peserta oleh fasilitator. Evaluasi para siswa mengacu pada tujuh indikator ini akan menjadi instrumen untuk melihat keberhasilan proses pelatihan; apakah pelatihan diterima dengan baik, bagaimana tanggapan para peserta, dan umpan balik apa saja yang mereka berikan.

$$
\text { Pendidikan }
$$


Dari 135 peserta, ada sebanyak 116 yang mengembalikan lembar evaluasi. Hasil evaluasi para siswa terlihat dalam grafik batang di bawah ini.

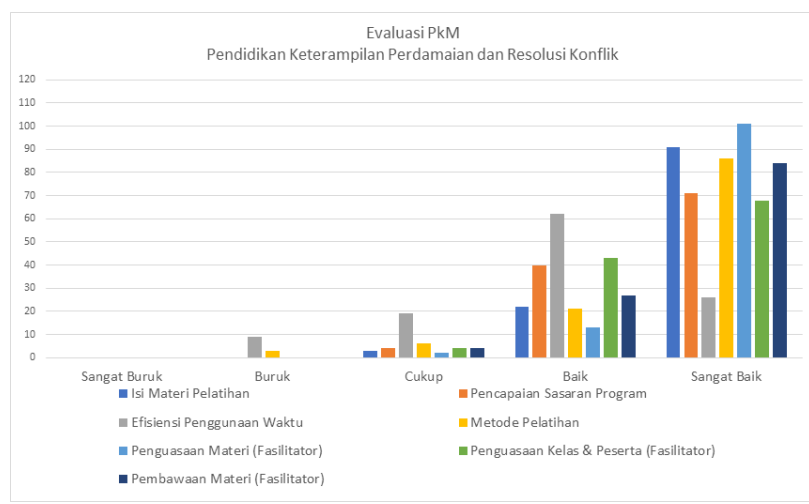

Gambar 2. Hasil Evaluasi Peserta

Berdasarkan grafik di atas dapat disimpulkan bahwa para siswa memberi pandangan positif terhadap proses pelatihan yang dilakukan. Secara umum, pelatihan dinilai sangat baik dan bermanfaat oleh para siswa.

Para siswa menilai sangat baik proses pelatihan dalam hal penguasaan materi oleh fasilitator, isi materi yang disampaikan, metode pelatihan yang dipakai, dan pembawaan materi. Penilaian para siswa ini mengindikasikan bahwa metode partisipatoris dan interaktif yang dipersiapkan untuk penyampaian materi pelatihan, sangat membantu para siswa dalam mengikuti proses pembelajaran.

Menyimak hasil evaluasi yang disampaikan para siswa, hal yang masih perlu diperbaiki dalam proses pelatihan selanjutnya adalah efisiensi penggunaan waktu. Dari jawaban kualitatif yang disampaikan para siswa, hal menonjol yang mereka sampaikan adalah harapan agar program sejenis bisa rutin dilakukan di sekolah. Pernyataan para siswa ini mengindikasikan adanya kebutuhan mereka untuk diperlengkapi dengan keterampilan perdamaian dan resolusi konflik.

\section{Dampak Awal}

Melalui kegiatan Pendidikan Keterampilan Perdamaian dan Resolusi Konflik yang diselenggarakan, para siswa Sekolah Lentera Harapan Jati Agung diharapkan mengalami perubahan sikap dalam jangka panjang. Untuk bisa mengalami perubahan sikap, sudah barang tentu para siswa harus terlebih dahulu memilik wawasan dan pengetahuan yang tepat tentang konflik dan perdamaian.

Untuk mendapatkan gambaran awal apakah pelatihan yang dilakukan berdampak terhadap wawasan dan pengetahuan para siswa, tim pelaksana menyiapkan intsrumen pre-test dan posttest. Lembar pre-test dan post-test terdiri dari tujuh pernyataan yang dibagi ke dua bagian pilihan.

Dari 135 peserta, sebanyak 114 peserta berpartisipasi mengisi pre-test dan post-test. Namun, hanya $49 \%$ yang valid dan bisa digunakan untuk pemetaan perubahan pengetahuan para siswa sebelum dan sesudah mengikuti rangkaian pelatihan. Sampel dikategorikan valid jika peserta: 1) mengisi lembar pre-test dan post-test; dan 2) seluruh pernyataan dipilih dan diisi dengan lengkap.

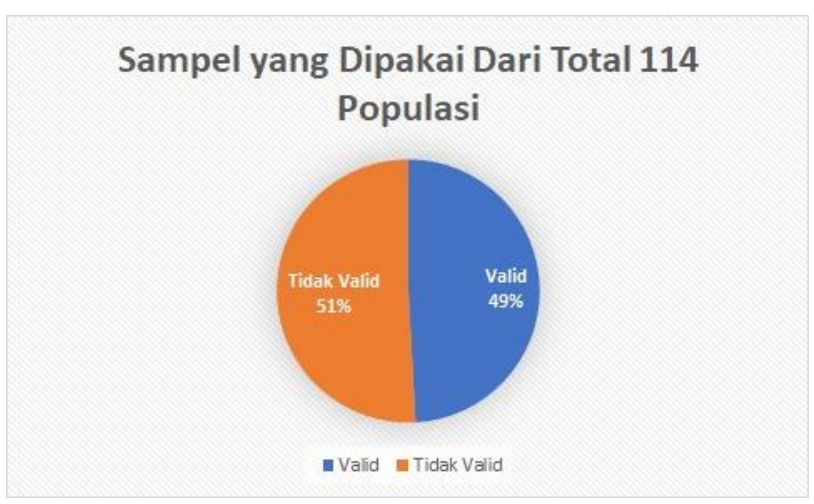

Gambar 3. Validitas Pre-Test dan Post-Test

Untuk pernyataan pertama, yang hendak dilihat adalah pengetahuan para siswa tentang hakikat konflik. Pada saat pre-test, $70 \%$ sampel menganggap bahwa konflik bersifat merusak hubungan, dan $30 \%$ berpendapat bahwa konflik bisa memperkuat hubungan.

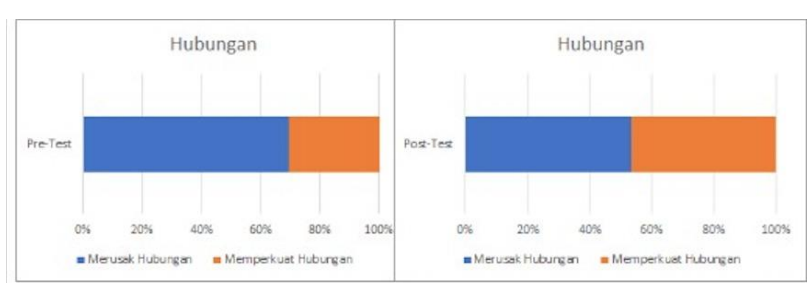

Pendidikan 
Gambar 4. Hakikat Konflik (Merusak/Memperkuat Hubungan)

Setelah rangkaian $\mathrm{PkM}$ selesai, terjadi perubahan di kedua pilihan. Lebih dari $40 \%$ peserta akhirnya tahu bahwa konflik juga bisa menjadi faktor yang memperkuat hubungan.

Pernyataan kedua hendak menilai pendekatan para siswa jika mereka terlibat dalam konflik. Hasil pengolahan data dari lembar pre-test menunjukkan bahwa sebagian besar siswa sudah paham bahwa konflik harus diselesaikan.

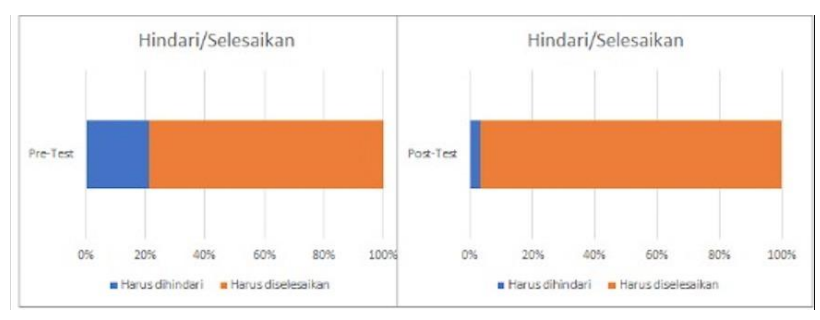

Gambar 5. Pendekatan terhadap Konflik (Hindari/Selesaikan)

Hampir $80 \%$ sampel setuju dengan pilihan ini, dan hanya $20 \%$ yang memilih bahwa konflik harus dihindari daripada diselesaikan. Meskipun sudah sebagian besar yang paham, setelah mengikuti pelatihan, tetap terjadi peningkatan. Hampir seluruh peserta setuju bahwa konflik harus diselesaikan, dan hanya segelintir, yaitu kurang dari $5 \%$ peserta, yang masih beranggapan bahwa konflik harus dihindari.

Cara penyelesaian konflik menjadi pemahaman selanjutnya yang dinilai melalui pernyataan ketiga. Hanya sedikit perubahan yang terjadi dalam hal pemahaman para peserta sebelum dan setelah mengikuti pelatihan ini. Namun, sebagian besar peserta sudah mengerti bahwa penyelesaian konflik perlu dilandaskan pada kesetaraan kekuatan.

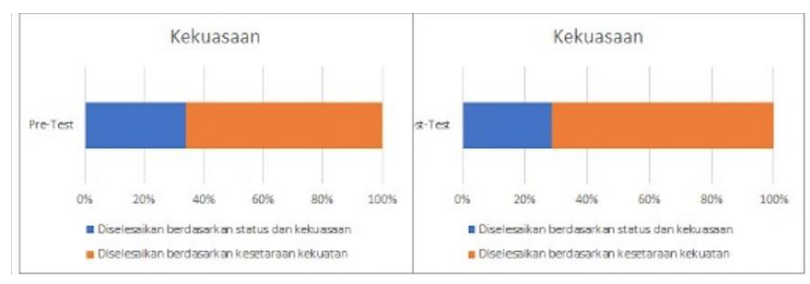

Gambar 6. Penyelesaian Konflik
Hasil pre-test menunjukkan lebih dari $60 \%$ peserta memilih untuk menyelesaikan konflik dengan menggunakan kesetaraan kekuatan, dan kurang dari $40 \%$ yang beranggapan bahwa status dan kekuasaanlah yang harus digunakan saat menyelesaikan konflik. Walaupun perubahannya hanya sedikit saat post-test, ada peningkatan sekitar 5\% sampel yang kemudian setuju menggunakan prinsip kesetaraan kekuatan dalam penyelesaian konflik.

Pernyataan keempat terdiri dari pilihan-pilihan tentang pertimbangan terhadap pendapat yang perlu diambil saat sedang berkonflik. Di awal pelatihan, lebih dari $70 \%$ sampel sudah sadar bahwa penting untuk mengakui dan menghargai perbedaan pendapat saat sedang berkonflik maupun sebelumnya. Di akhir pelatihan, lebih dari $80 \%$ siswa sepakat bahwa perbedaan pendapat penting untuk diakui dan dihargai, sehingga tidak boleh diabaikan begitu saja.

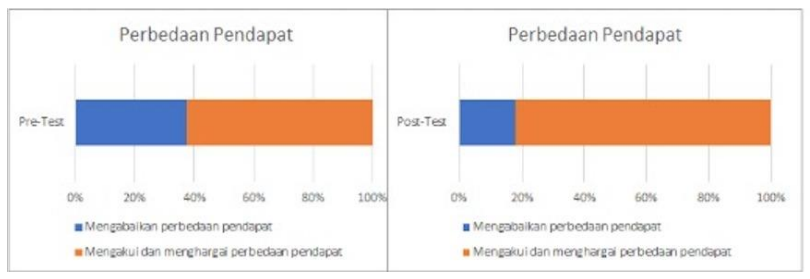

Gambar 7. Pertimbangan terhadap Pendapat

Pernyataan selanjutnya hendak mengetahui pemahaman para siswa tentang hikmah dari konflik. Para siswa menentukan pandangan mereka apakah konflik bisa mendewasakan pihak-pihak yang berkonflik, atau konflik tidak menghasilkan apaapa.

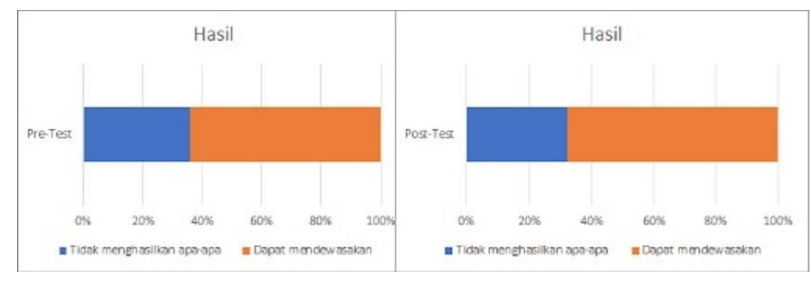

Gambar 8. Hikmah Konflik

Walaupun tidak ada perubahan yang signifikan untuk pemahaman ini, namun hasil pretest maupun post-test menunjukkan bahwa lebih dari 60\% sampel sepakat bahwa konflik dapat mendewasakan untuk para pihak yang terlibat.

$$
\text { Pendidikan }
$$


Untuk pernyataan keenam, yang hendak dilihat adalah usaha yang seharusnya para siswa lakukan untuk mencapai resolusi konflik. Para siswa memilih apakah jika konflik terjadi mereka sebaiknya saling menyalahkan, atau dengan adanya konflik mereka terdorong untuk saling memahami guna mencapai kesepakatan.

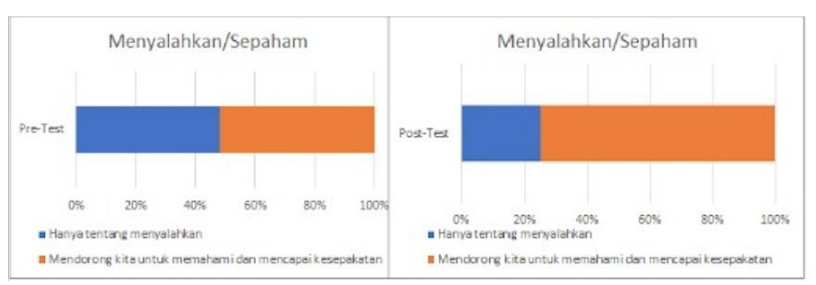

Gambar 9. Sikap Menghadapi Konflik

Sebelum diberi pelatihan dan pemahaman tentang perdamaian dan konflik, hampir setengah dari sampel menganggap bahwa saling menyalahkan adalah apa yang seharusnya mereka lakukan. Namun, setelah pelatihan, hampir $80 \%$ sampel sepakat bahwa mereka sepatutnya tidak saling menyalahkan, melainkan berusaha untuk saling memahami guna mencapai kesepakatan sebagai resolusi yang tepat dari konflik yang mereka hadapi.

Pernyataan yang terakhir dimaksudkan untuk mendapatkan gambaran pemahaman para siswa tentang keuntungan dari sebuah konflik. Di awal pelatihan, hampir setengah dari sampel beranggapan bahwa setelah konflik hanya ada satu pihak yang menang dan satu yang kalah. Lebih dari $40 \%$ siswa memilih opsi ini. Namun, setelah akhir kegiatan, secara drastis para siswa kemudian paham bahwa konflik pun dapat menghasilkan solusi yang menyenangkan untuk masing-masing pihak yang terlibat. Hampir 90\% sampel akhirnya memilih pilihan ini di lembar post-test.

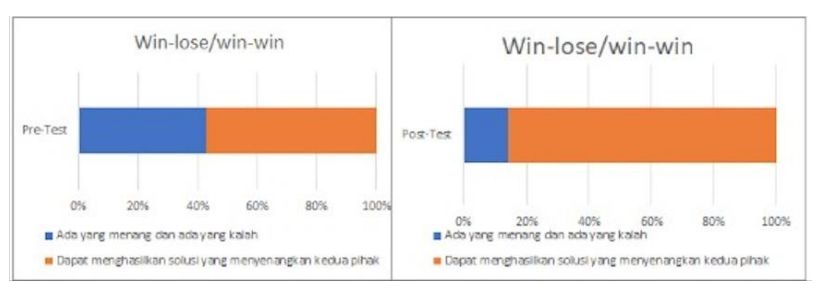

Gambar 10. Hasil Akhir Konflik

Sebagai tindak lanjut, tim Pendidikan Keterampilan Perdamaian dan Resolusi Konflik dan
Sekolah Lentera Harapan Jati Agung telah menyepakati dua hal. Pertama, akan dilaksanakan Training for Trainer bagi para guru sekolah yang sedianya akan berlangsung pada pertengahan tahun 2020, tetapi terkendala pandemi. Kedua, menyambung kesepakatan pertama, akan dilaksanakan replikasi kegiatan setiap tahun dengan guru-guru sekolah beserta siswa/i terpilih sebagai fasilitator dan tim dari UPH sebagai pendamping.

Di samping itu, pandemi telah mendorong tim Pendidikan Keterampilan Perdamaian dan Resolusi Konflik untuk menyesuaikan metode pelatihan. Semula dan idealnya kegiatan dilaksanakan melalui pelatihan tatap muka; opsi tersebut tentu tidak dapat dipilih saat ini. Kini tim tengah mengembangkan metode pendidikan perdamaian lain dengan memanfaatkan media sosial (Instagram dan YouTube) yang diharapkan dapat menjangkau lebih banyak kalangan, khususnya pemuda.

\section{KESIMPULAN}

Secara umum, dengan perubahan yang terlihat, kegiatan pelatihan yang dilaksanakan dapat dinilai telah memberi pengaruh terhadap wawasan dan pengetahuan para siswa, khususnya mengenai konflik dan perdamaian. Meskipun demikian, tim pelaksana menilai bahwa bahwa fondasi dan pengajaran tentang cara-cara bersosialisasi yang para siswa terima selama bersekolah di Sekolah Lentera Harapan Jati Agung juga ikut berkontribusi terhadap hasil baik yang dicapai. Melalui kegiatan Pengabdian kepada Masyarakat ini para siswa semakin diperlengkapi dengan wawasan, pengetahuan, dan keterampilan dalam hal perdamaian dan resolusi konflik. Diharapkan, perubahan orientasi yang sudah terjadi selama pelatihan, akan diikuti dengan perubahan sikap dan perilaku dalam jangka panjang.

\section{UCAPAN TERIMA KASIH}

Tim pelaksana pelatihan Pendidikan Keterampilan Perdamaian dan Resolusi Konflik mengucapkan terima kasih kepada Sekolah Lentera Harapan Jati Agung Lampung atas kesediaan serta antusiasme yang diberikan sebelum dan selama kegiatan berlangsung. 


\section{REFERENSI}

Firawati, T. (2015). Belajar Hidup dengan Musuh Demokrasi. In H. Mubarok \& I. Rafsadi (Eds.). Sisi Gelap Demokrasi Indonesia Kekerasan Masyarakat Madani di Indonesia (103124). Jakarta: Pusat Studi Agama dan Demokrasi (PUSAD) Yayasan Paramadina.

Galtung J. \& Fischer D. (2013). Positive and Negative Peace. In: Johan Galtung. SpringerBriefs on Pioneers in Science and Practice, vol 5. Springer, Berlin, Heidelberg. https://doi.org/10.1007/978-3-642-32481-9 17

Lederach, J. P. (2003.) The Little Book of Conflict Transformation. Intercourse. Philadelphia: Good Books.

Mac Ginty, R. (2016). No War, No Peace: The Rejuvenation of Stalled Peace Processes and Peace Accords. New York: Palgrave Macmillan.

Maghroori, R. \& Ramberg, B. (1982). Globalism Versus Realism: International Relations, Third Debate. Boulder, Colorado: Westview Press, Inc.

Muslihah, E. (2015, February 9). Komnas HAM: Lampung Masuk Tiga Besar Daerah Rawan Konflik. Kompas. Diakses dari https://regional.kompas.com/read/2015/02/09/17214 66/Komnas.HAM.Lampung.Masuk.Tiga.Besar.Dae rah.Rawan.Konflik.

Nasution, E. (2017, 14-15 November). Indonesian Democracy: What to Do with Political Violence? Paper presented at the Third International Conference on Social and Political Sciences (ICSPS 2017). https://dx.doi.org/10.2991/icsps-17.2018.6
Raider, E., Coleman, S., \& Gerson, J. (2006). Teaching Conflict Resolution Skills in a Workshop. In Deutsch, M., Coleman, P. T., \& Marcus, E. C. (Eds). The Handbook of Conflict Resolution Theory and Practice (695-725). San Francisco, CA: John Wiley \& Sons, Inc.

Ramsbotham, O., Woodhouse, T., \& Miall, H. (2008). Contemporary Conflict Resolution. Cambridge: Polity Press.

Sandy, S. V. (2006). The Development of Conflict Resolution Skills Preschool to Adulthood. In: Deutsch, M., Coleman, P. T., \& Marcus, E. C. (Eds). The Handbook of Conflict Resolution Theory and Practice (pp. 356-388). San Francisco, CA: John Wiley \& Sons, Inc.

Stein, A. (2004). The Individual and Global Peace Building: A Transformational Perspective. In: Genest, M. A. (Ed.). Conflict and Cooperation: Evolving Theories of International Relations (pp. 565-581). Belmont, CA: Wadsworth.

Tambunan, E. (2008). Modul Pendidikan Perdamaian untuk Sekolah Menengah Atas (SMA) dan Sekolah Menengah Kejuruan (SMK). Jakarta: Majelis Pendidikan Kristen di Indonesia.

Yemenici, A. (2016). Peace Education: Training for an Evolved Consciousness of NonViolence. All Azimuth: A Journal of Foreign Policy and Peace, 5(1), 5-27. 